\title{
Probable neuroimmunological link between Toxoplasma and cytomegalovirus infections and personality changes in the human
} host

\author{
Martina Novotná ${ }^{1}$, Jitka Hanusova ${ }^{1}$, Jiří Klose ${ }^{2}$, Marek Preiss ${ }^{3}$, Jan Havlicek ${ }^{4}$, \\ Kateřina Roubalová 5 and Jaroslav Flegr*1
}

Address: ${ }^{1}$ Department of Parasitology, Charles University, Viničná 7, Prague 128 44, Czech Republic, ${ }^{2}$ Central Medical Psychological Unit, Central Military Hospital, U vojenské nemocnice 1200, Prague 169 02, Czech Republic, ${ }^{3}$ Prague Psychiatric Clinic, Ústavní 91, Prague, 180 00, Czech Republic, ${ }^{4}$ Department of Anthropology, Faculty of Humanities, Charles University, Husnikova 2075, 15800 Prague 13, Czech Republic and ${ }^{5}$ National Reference Laboratory for Herpesviruses, National Institute of Public Health, Šrobárova 48, Prague 100 42, Czech Republic

Email: Martina Novotná - vitakova@seznam.cz; Jitka Hanusova - jitka_hanusova@hotmail.com; Jiří Klose - klose@uvn.cz; Marek Preiss - preiss@pcp.lf3.cuni.cz; Jan Havlicek - jan.havlicek@fhs.cuni.cz; Kateřina Roubalová - herpesvir@szu.cz; Jaroslav Flegr* - flegr@cesnet.cz

* Corresponding author

Published: 06 July 2005

BMC Infectious Diseases 2005, 5:54 doi:10.1 I86/147/-2334-5-54
Received: 19 November 2004

Accepted: 06 July 2005

This article is available from: http://www.biomedcentral.com/I47I-2334/5/54

(C) 2005 Novotná et al; licensee BioMed Central Ltd.

This is an Open Access article distributed under the terms of the Creative Commons Attribution License (http://creativecommons.org/licenses/by/2.0), which permits unrestricted use, distribution, and reproduction in any medium, provided the original work is properly cited.

\begin{abstract}
Background: Recently, a negative association between Toxoplasma-infection and novelty seeking was reported. The authors suggested that changes of personality trait were caused by manipulation activity of the parasite, aimed at increasing the probability of transmission of the parasite from an intermediate to a definitive host. They also suggested that low novelty seeking indicated an increased level of the neurotransmitter dopamine in the brain of infected subjects, a phenomenon already observed in experimentally infected rodents. However, the changes in personality can also be just a byproduct of any neurotropic infection. Moreover, the association between a personality trait and the toxoplasmosis can even be caused by an independent correlation of both the probability of Toxoplasma-infection and the personality trait with the third factor, namely with the size of living place of a subject. To test these two alternative hypotheses, we studied the influence of another neurotropic pathogen, the cytomegalovirus, on the personality of infected subjects, and reanalyzed the original data after the effect of the potential confounder, the size of living place, was controlled.
\end{abstract}

Methods: In the case-control study, 533 conscripts were tested for toxoplasmosis and presence of anti-cytomegalovirus antibodies and their novelty seeking was examined with Cloninger's $\mathrm{TCl}$ questionnaire. Possible association between the two infections and $\mathrm{TCl}$ dimensions was analyzed.

Results: The decrease of novelty seeking is associated also with cytomegalovirus infection. After the size of living place was controlled, the effect of toxoplasmosis on novelty seeking increased. Significant difference in novelty seeking was observed only in the largest city, Prague.

Conclusion: Toxoplasma and cytomegalovirus probably induce a decrease of novelty seeking. As the cytomegalovirus spreads in population by direct contact (not by predation as with Toxoplasma), the observed changes are the byproduct of brain infections rather than the result of manipulation activity of a parasite. Four independent lines of indirect evidence, namely direct measurement of neurotransmitter concentration in mice, the nature of behavioral changes in rodents, the nature of personality changes in humans, and the observed association between schizophrenia and toxoplasmosis, suggest that the changes of dopamine concentration in brain could play a role in behavioral changes of infected hosts. 


\section{Background}

The protozoan parasite Toxoplasma gondii specifically influences the behavior of intermediate hosts. Infected mice have impaired motor performance [1], deficits in learning capacity and memory [2], higher activity levels both in novel and familiar environments [3-7], lower ability of discriminating between familiar and novel surroundings $[3,4,8]$, and longer reaction times [9]. Infected rats have higher activity levels [10], lower neophobia [11], reduced learning capacity [2] and reduced specific predator avoidance [12]. Humans with latent toxoplasmosis have significantly deteriorated psychomotor performance (prolonged simple reaction times) in comparison with Toxoplasma-negative subjects [13] and are at higher risk of traffic accidents [14]. Subjects with latent toxoplasmosis are known to show specific changes in some personality dimensions as measured by the 16PF questionnaire [1517] and Cloninger's TCI (Temperament and Character Inventory) [18]. Recently, Flegr et al. [18] used changes in the TCI dimension novelty seeking for monitoring possible shifts in dopaminergic activity in the brain of infected subjects. Increase in dopamine levels in infected subjects was expected based on direct measurement of neurotransmitter levels in animals [19] and the reported positive correlation between schizophrenia and toxoplasmosis [2025] or risk factors [26-28]. Same authors expect that the background level of dopamine in the basal ganglia negatively correlates with the personality dimension novelty seeking as measured with Cloninger's TCI questionnaire [29-33]. Therefore, the authors of previous study interpreted lower novelty seeking in the subset of Toxoplasmainfected subjects as an indirect indicator of increased dopamine levels in brain tissue. An important caveat of the published study was failure to adjust for size of place of residence. The risk of Toxoplasma infection in the Czech Republic is known to correlate negatively with size of place of residence [34]. Since several personality factors could also correlate with this variable, it is difficult to tell to what extent the negative correlation between novelty seeking and latent toxoplasmosis may be biased by the correlation between novelty seeking and size of place of residence and between size of place of residence and the risk of Toxoplasma infection. In this light, it would be of relevance to test the effect of another neurotropic pathogen with a different life cycle and transmission route on personality in infected humans. Human cytomegalovirus seems to be a suitable model for the study among the Czech population.

Both the human cytomegalovirus (CMV) and protozoon Toxoplasma gondii are extremely common human pathogens. Depending on hygiene standards and habits, socioeconomic parameters and population demographic structure, the prevalence rates of CMV and Toxoplasma in different countries vary between $40-100 \%$ and $20-70 \%$, respectively. CMV is transmitted by close contact between infected subjects, via blood or blood products, sexual intercourse, or parentally. On the other hand, Toxoplasma is transmitted either by consumption of raw or undercooked meat with tissue pseudocysts or by ingestion of food or water contaminated with cat feces containing oocysts of the parasite. Infection of pregnant woman with CMV or Toxoplasma, especially in the first trimester of pregnancy, frequently results in severe damage to the nervous system of the foetus or abortion $[35,36]$. Postnatally acquired infections in immunocompetent subjects are probably life-long but usually harmless and asymptomatic. However, the latent CMV or Toxoplasma infections can be activated in immunocompromised patients, e.g. those with AIDS, or immunosuppressed transplant recipients [37-39]. Here, the activation may lead to dissemination of virus or Toxoplasma to various tissues, including those of the nervous system [40], with possible fatal outcome due to viral or toxoplasmic encephalitis. In encephalitis patients with toxoplasmosis the lesions are mainly localized in the hemisphere gray matter, thalamus and basal ganglia [41] while in patients with CMV encephalitis they are found mainly in the periventricular areas, hemisphere gray matter, cerebellum and spinal cord [40].

The main aim of the present study was to test whether the negative association between infection and novelty seeking can also be found for another very common neurotrophic pathogen, human cytomegalovirus, which is not transmitted by predation but by direct host-host contact. Another aim of the study was to establish whether the psychological effect of latent toxoplasmosis was evident after adjustment for an important confounder, i.e. size of place of residence. For these purposes, 533 conscripts previously tested for latent toxoplasmosis and examined with Cloninger's TCI questionnaire were screened for antiCMV antibodies. Possible association between the two infections and TCI dimensions was analyzed.

\section{Methods Subjects}

All personality testing was performed at the Central Military Hospital in Prague. Personality data were collected during regular psychological examinations of conscripts (men), aspirants to two military specializations, namely to those of military guards (guards) and military castle guards (presidential guards). All of the subjects were asked to voluntarily participate in the research project and to sign the informed consent form, if enrolled. About 80 $\%$ of the subjects consented to the use of their psychological test results for the research project purposes and provided $5 \mathrm{ml}$ of blood for serological testing. The experimental subjects were recruited in two drafts in July 2000 and January 2001. Only those aged 19-21 were 
enrolled. By this we not only obtained a more age-homogeneous experimental set of 533 men but also excluded potential outliers, i.e., those who had avoided regular compulsory military service for more than 3 years and also all four subjects that declared higher (university) education. Reliable information on the size of place of residence was available for 299 enrollees, divided into three categories: those living in villages and small cities $(<10$ thousand population), those living in large cities (10-100 thousand population) and those living in the Czech capital, Prague (1.2 million population). The results of all analyses were virtually the same if the study subjects were divided into four categories ( $<10$ thousand, $10-50$ thousand, 50-100 thousand, $>100$ thousand). Similar results were also obtained if the categorization was done on the basis of size of the place where the subject had spent his childhood instead of that of his current place of residence. The recruitment of subjects and the data handling was in accordance with current rules in Czech legislation.

\section{Personality tests}

Personality testing was performed with a computerized form of the TCI (Temperament and Character Inventory) [42] as translated by Kožený and Tisanská [43], with translation of two questions being modified and Cloninger's validation scale being substituted with Eysenck's Lie scale EP/R. The final questionnaire [44] contained 238 TCI items, including 12 Lie scale items. The subjects received written instructions to press the YES or NO key for particular items, depending on whether the sentence on the computer screen characterized or did not characterize their usual and most probable behavior or feelings in the given situations. The TCI questionnaire recognizes four dimensions of temperament, namely Harm avoidance (HA), Novelty seeking (NS), Reward Dependence (RD) and Persistence (PE), and three dimensions of character, i.e., Self-directedness (SD), Cooperativeness (C) and Self-transcendence (ST).

Testing of intelligence was performed with the Otis questionnaire [45]. The Otis test is a standard verbal intelligence test used by the Czech Army. It consists of 32 questions focused on understanding of the given relationships, linguistic sensitivity, and vocabulary skills. It requires definitions of the concepts as expressed by the closest descriptive characteristics, selection of concepts according to common characteristics of objects, choice of antitheses, rejection of disparate concepts and explanation of proverbs.

\section{Immunological tests for toxoplasmosis and CMV}

All serological tests were carried out in the National Reference Laboratory for toxoplasmosis and the National Reference Laboratory for herpes viruses of the National Institute of Public Health, Prague. Specific anti Toxoplasma
IgG and IgM antibody concentrations were determined by ELISA (IgG: SEVAC, Prague, IgM: TestLine, Brno), optimized for early detection of acute toxoplasmosis [46], and complement fixation test (CFT) (SEVAC, Prague) which is more sensitive and therefore more suitable for the detection of old $T$. gondii infections [47]. CFT titres of antibodies to Toxoplasma in sera were measured at dilutions between $1: 8$ and $1: 1024$. The subjects with negative results of IgM ELISA (positivity index<0.9) and CFT titres higher than $1: 8$ were considered latent-toxoplasmosis positive. Specific antiCMV IgG antibodies were measured by quantitative ELISA (ETI-CYTOK-G plus, DiaSorin). Antibody concentration was expressed in arbitrary units (AU). Individuals with $\mathrm{AU}<40$ were considered seronegative for CMV.

\section{Statistical analysis}

The Statistica ${ }^{\circledast}$ V.6.0 was used for all statistical testing, i.e., for Log-linear analyses, ANOVA, ANCOVA, Kendall nonparametric test, and linear regression. The results of testing of ANCOVA assumptions, namely of the testing of normality of data distribution, normality of residuals and homogeneity of variances, were nonsignificant for all studied models.

\section{Results}

Five hundred thirty-three conscripts were tested for specific immunity against CMV and Toxoplasma. The prevalence rates of CMV and Toxoplasma infections were $50.5 \%$ and $25.0 \%$, respectively. No statistical association was found between the two infections: CMV infection was detected in $48.9 \%$ of Toxoplasma-infected and $51.0 \%$ of Toxoplasma-free subjects. Log-linear analysis of the categorical factors Toxoplasma infection, CMV infection, education level and size of place of residence revealed just one significant interaction, namely the negative correlation between Toxoplasma infection and the size of place of residence. The difference between the models with and without this interaction was statistically significant $\left(\mathrm{Chi}^{2}=\right.$ 7.89, $\mathrm{df}=2, \mathrm{P}=0.019)$. The results of two-way ANOVA with the factors Toxoplasma infection and CMV infection showed that both CMV infection $\left(\mathrm{F}_{1,529}=7.37, \mathrm{P}=0.007\right)$ and Toxoplasma infection $\left(\mathrm{F}_{1,529}=6.32, \mathrm{P}=0.012\right)$ were associated with lower novelty seeking scores (Fig. 1). Toxoplasma infection was also associated with higher selftranscendence scores (14.9 vs. $13.8, \mathrm{~F}_{1,529}=4.52, \mathrm{P}=$ $0.034)$. The results also showed a significant effect of the interaction between CMV and Toxoplasma infections on harm avoidance $\left(F_{1,529}=5.10, P=0.024\right)$ (Fig. 2). Neither the effect of toxoplasmosis on self-transcendence nor the effect of the interaction between CMV and Toxoplasma infection on harm avoidance was significant after Bonferroni correction for twelve statistical tests $(P=0.408$ and $P$ $=0.284$, respectively) . 


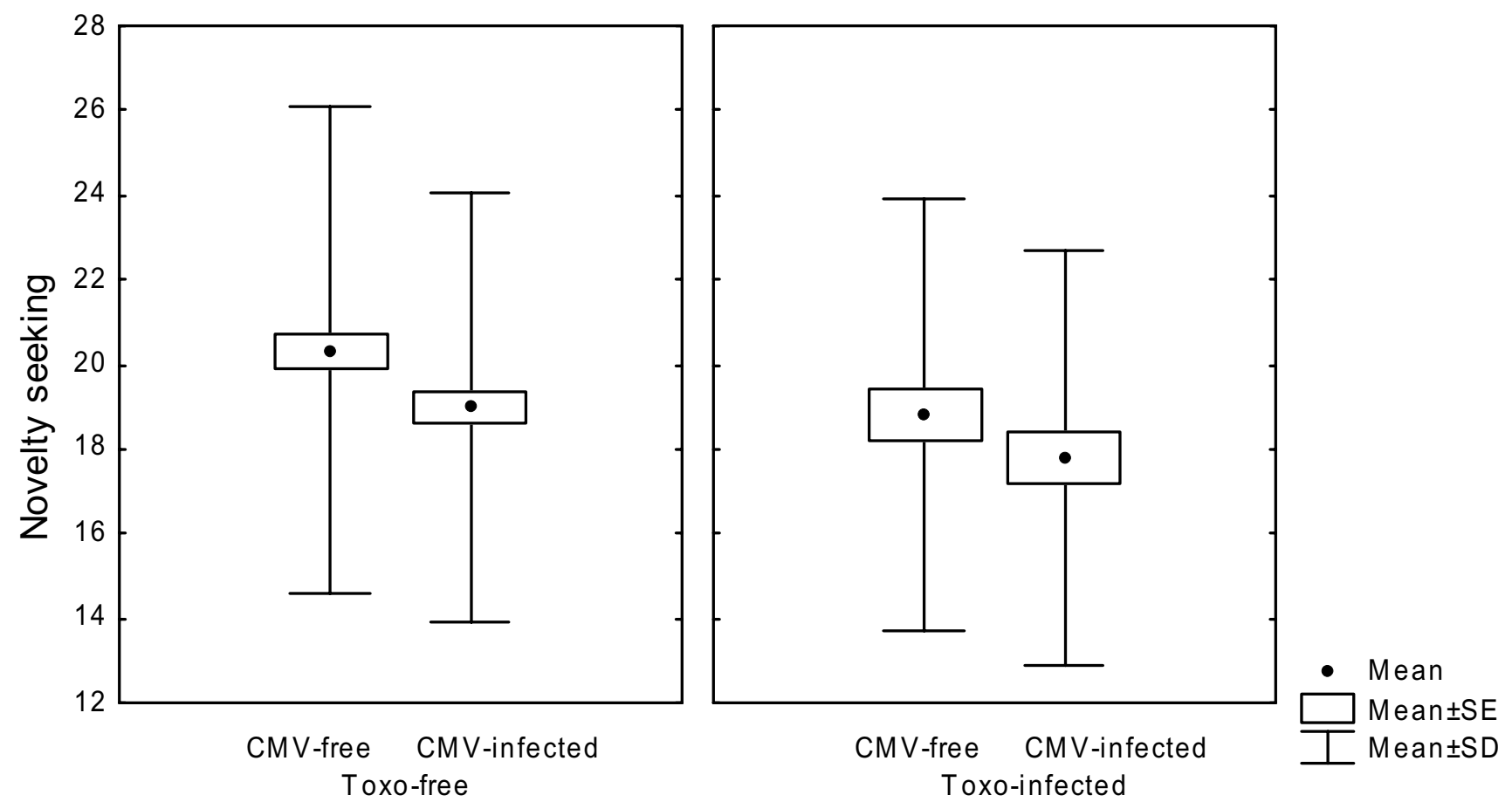

Figure I

Novelty seeking in conscripts infected with cytomegalovirus and Toxoplasma gondii.

Previous studies suggested that several confounders such as the level of education, size of place of residence, intelligence and motivation of experimental subjects could bias the TCI dimensions. Therefore, we repeated the analyses with the independent factors CMV infection, Toxoplasma infection, military profession (the factor probably correlated with the motivation of subjects), size of place of residence and intelligence as measured using the OTIS test (continuous variable). The results of this ANCOVA test concerning the association between novelty seeking and the CMV infections were similar to those obtained with the ANOVA test but the results of ANCOVA and ANOVA for Toxoplasma infection differed. CMV infected subjects were lower in novelty seeking $\left(\mathrm{F}_{1,293}=7.80, \mathrm{P}=\right.$ $0.006)$. The differences in novelty seeking and self-transcendence between Toxoplasma-infected and Toxoplasmafree subjects fall below the formal level of statistical significance $\left(\mathrm{F}_{1,293}=1.71, \mathrm{P}=0.19\right.$ for $\mathrm{NS}$ and $\mathrm{F}_{1,293}=3.84, \mathrm{P}=$ 0.051 for ST). At the same time, the analysis showed highly significant effect of interaction toxoplasmosis-size of place of residence on novelty seeking $\left(\mathrm{F}_{2,293}=6.81, \mathrm{P}=\right.$ $0.001)$. Toxoplasma infection had only small impact on novelty seeking in the subjects living in settlements with less than 10000 population $\left(\mathrm{F}_{1,146}=0.77, \mathrm{P}=0.380\right)$, being associated with non-significantly higher novelty seeking scores in residents of the cities with 10-100 thousand population $\left(\mathrm{F}_{1,79}=2.21, \mathrm{P}=0.142\right)$, and with low novelty seeking scores in Prague enrollees $\left(F_{1,66}=16.46, P\right.$ $=0.0002$ ) (Fig. 3). Similarly, association between CMV infection and novelty seeking was absent for inhabitants of villages and small cities $\left(\mathrm{F}_{1,146}=0.59, \mathrm{P}=0.451\right), \mathrm{CMV}$ infection being associated with lower novelty seeking scores for subjects living both in the cities with 10-100 thousand population and in Prague $\left[\left(\mathrm{F}_{1,79}=7.75, \mathrm{P}=\right.\right.$ $0.007),\left(F_{1,66}=5.66, P=0.021\right)$, respectively] (Fig. 4). The strength of effect of interaction between CMV and Toxoplasma infections on harm avoidance increased after adjustment for confounders $\left(\mathrm{F}_{2,293}=7.98, \mathrm{P}=0.005 ; \mathrm{P}=\right.$ 0.06 after Bonferroni correction).

If the infection induces a shift in the personality dimension, the amount of personality shift should correlate with the concentration of specific antibodies. Such an effect (significant in one-tailed tests) was observed for both the CFT titre of anti-Toxoplasma (Kendal Tau $=-0.14, \mathrm{P}=$ $0.015)$ and the concentration of anti- CMV antibodies $\left(\mathrm{F}_{1,229}=3.1, \mathrm{P}=0.079\right)$.

Lower intelligence scores and education level in Toxoplasma-infected subjects as reported previously were not 

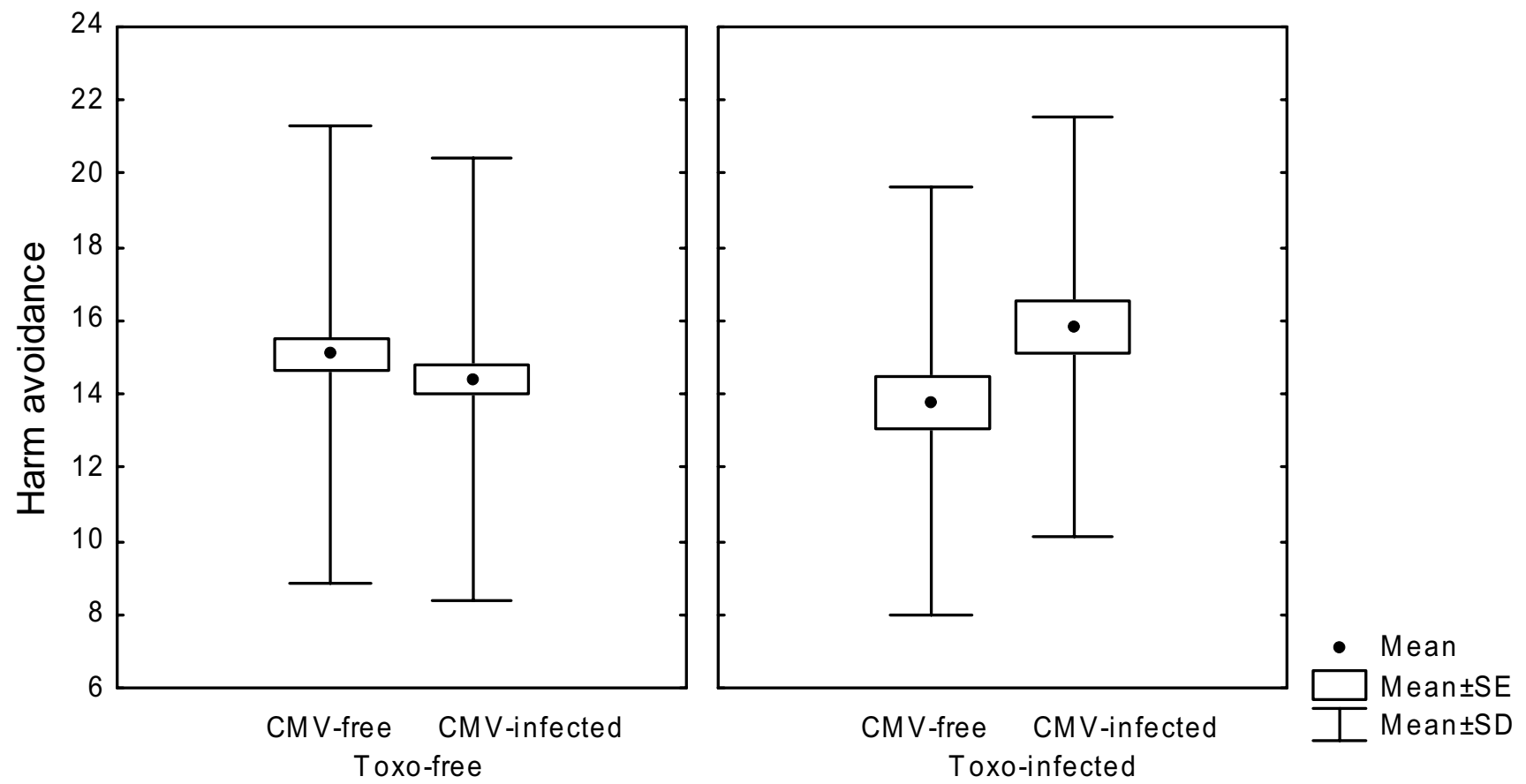

Figure 2

Harm avoidance in conscripts infected with cytomegalovirus and Toxoplasma gondii.

observed for either CMV infection or toxoplasmosis in the present study. In fact, slightly lower intelligence was recorded in CMV-free than CMV-infected subjects (96.3 vs. 97.8, $\mathrm{F}_{1,293}=1.452, \mathrm{P}=0.229$ ). The significant effect of Toxoplasma infection on intelligence also disappeared after adjustment for the confounder size of place of residence $\left(F_{1,293}=0.003, P=0.959\right)$.

\section{Discussion}

Our results showed that CMV infected subjects had lower scores in the personality dimension novelty seeking than the CMV-free subjects. Novelty seeking in infected subjects negatively correlated with levels of anti-CMV antibodies. Negative correlation was also found between novelty seeking and Toxoplasma-infection in Prague, while in villages and smaller cities the correlation was not significant. The effect of both infections, although highly significant, was rather low, explaining about $2 \%$ of total variability of the novelty seeking in our experimental set. The study also revealed several other significant effects CMV or Toxoplasma infections and their interaction on personality traits. While the effect of the infections on novelty seeking was a priori expected, other effects were revealed by an ex post analysis. Therefore, the results concerning the other effects have to be corrected for multiple statistical tests. After the Bonferroni's correction for multiple tests, no ex post revealed effect remained significant.

The lower values novelty seeking in the Toxoplasma-positive subjects suggest that infected men are on average more reflective, tend to require more detailed information when making an opinion and are not easily distracted. They are also more reserved, slow, controlled; they do not waste their energy and feelings. They tend to be organized, methodical, and prefer activities with strict rules and regulations. The association between latent toxoplasmosis and low novelty seeking scores has already been reported [18]. The present study showed that the relation between toxoplasmosis and novelty seeking was not caused by parallel correlations between the risk of Toxoplasma infection and size of place of residence and between size of place of residence and novelty seeking scores. Surprisingly, toxoplasmosis and CMV infections were associated with considerably lower novelty seeking scores only in large cities. There were no significant differences in novelty seeking between infected and pathogens-free subjects in settlements with fewer than 10 thousand population (CMV) or fewer than 100 thousand population (Toxoplasma). At present we have no explanation for this phenomenon. 


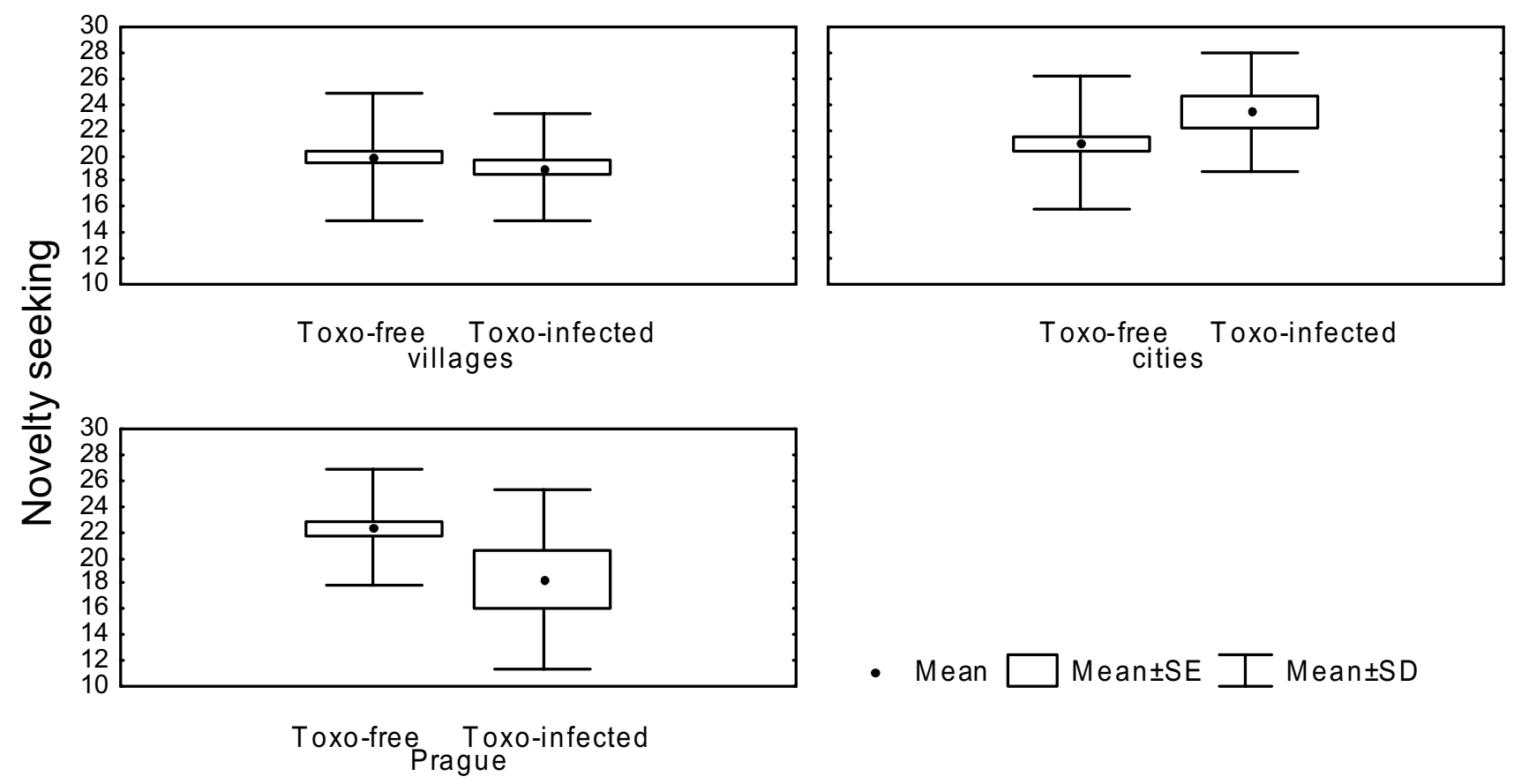

Figure 3

Effects of toxoplasmosis and size of place of residence on the TCI dimension novelty seeking. Villages of $<10000$ population, cities of $>10,000$ and $<100,000$ population, Prague (I,200,000 population).

A previous study performed on a larger set of experimental subjects revealed that Toxoplasma-infected subjects scored lower in verbal intelligence as measured with the Otis test and showed lower probability of achieving secondary education than Toxoplasma-free subjects [18]. It was demonstrated in several countries including the Czech Republic [34] that prevalence of toxoplasmosis is higher in villages and small cities than in larger cities. At the same time, the probability of achieving higher education and possibly also higher verbal intelligence could positively correlate with the size of place of residence. Therefore, the observed effects of toxoplasmosis can in fact reflect a parallel influence of size of place of residence (and corresponding life style) on a) the risk of acquiring Toxoplasma infection and b) probability of achieving secondary education and higher verbal intelligence. This model was strongly supported by the results of the present study. All associations between Toxoplasma infection and education level or intelligence disappeared after adjustment for the effect of place of residence. It is also noteworthy that CMV infection, which shows a similar prevalence rates in villages and small and large cities, has no association with education level or intelligence.
Neither the psychopathological antecedents nor the preinfection personality data of the subjects were available for our analysis. Based on a case-control study, it is not possible to tell whether there is a causal relation between two statistically associated factors (e.g. infection and lower novelty seeking scores) and/or to determine the direction of such a relation. Theoretically, the infection could induce personality changes, personality factors may have influenced the risk of infection and possibly a third factor, such as the socioeconomic status, may have played a role in both personality dimensions and the risk of infection. In our view, however, the most parsimonious explanation is that the infection, more precisely the presence of pathogens in the brain of infected subjects, induces changes in neurotransmitter levels, causing in turn changes in TCI personality dimensions. This hypothesis is based on several lines of indirect evidence:

a) Two different neurotropic pathogens with quite different life cycles and transmission routes are associated with the same psychological effect. This makes the existence of a third factor responsible for both lower novelty seeking scores and higher risk of infection rather unlikely. 


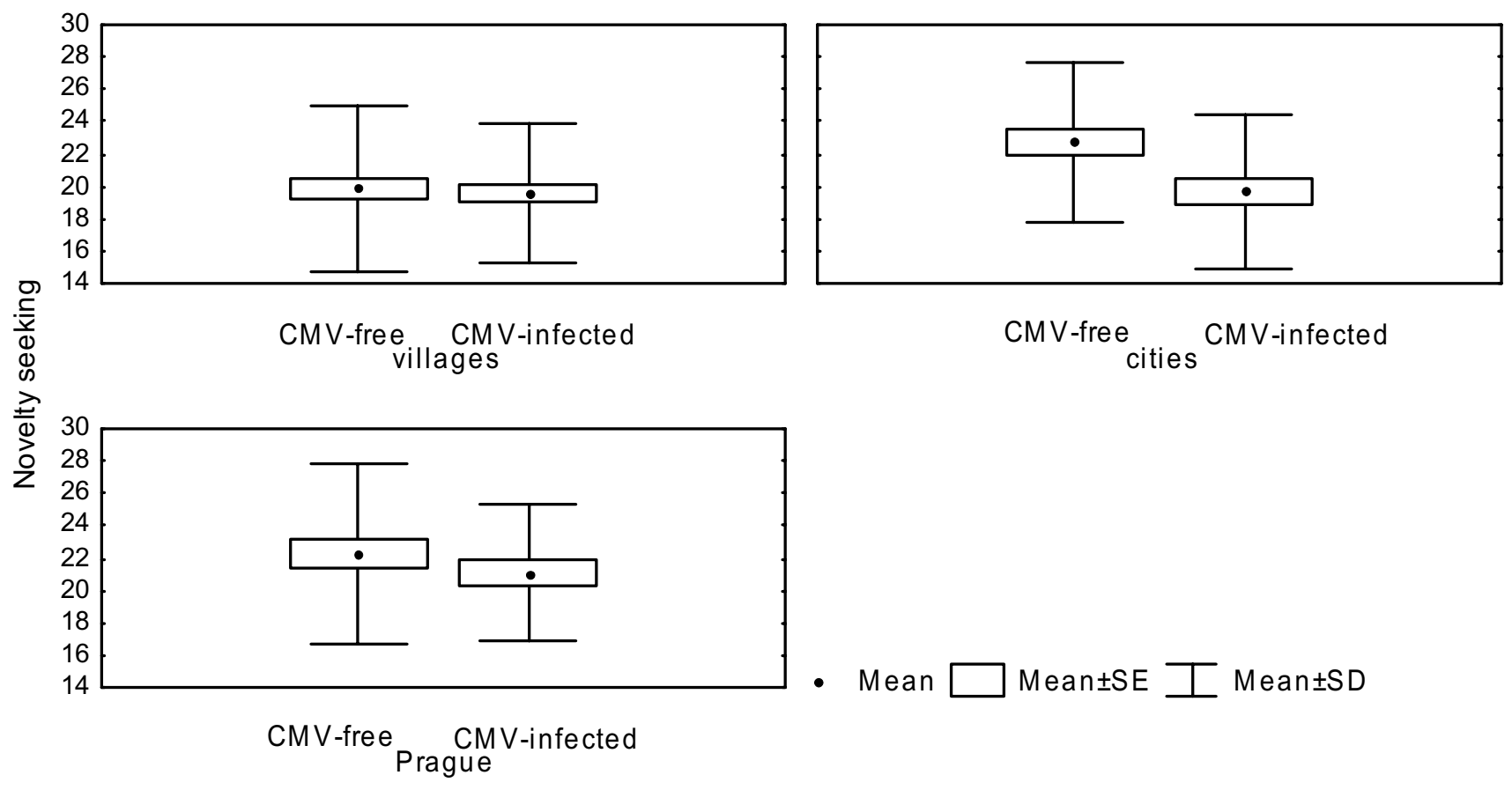

Figure 4

Effects of CMV infection and size of place of residence on the TCI dimension novelty seeking. Villages of $<10000$ population, cities of $>10,000$ and $<100,000$ population, Prague (I,200,000 population).

Moreover, the existence of such a factor would cause a statistical association between Toxoplasma and CMV infections. However, CMV infection was detected with equal frequency among Toxoplasma-free and Toxoplasma-infected subjects.

b) The existence of correlation between novelty seeking scores and levels of specific antibodies (significant in onetailed tests) was observed for both Toxoplasma and CMV. Such a correlation between the intensity of personality change and specific immunity could hardly be found if novelty seeking would influence the risk of infection or if an unknown factor would independently influence both novelty seeking and the risk of infection.

c) A decrease in neophilia in naturally neophilic mice and a decrease of neophobia of naturally neophobic rats, probably caused by lower ability of discriminating between familiar and novel surroundings, was also observed in animals experimentally infected with Toxoplasma $[3,4,8]$, and a related behavioral effect (the apomorphine-mediated decrease of prepulse inhibition) was observed in rats infected with CMV [48]. Therefore, the direction of the causal relation between novelty seekingrelated behavioral changes and Toxoplasma/CMV infec- tions has already been experimentally established in rodents.

d) Lower novelty seeking scores are claimed by several authors [29-33] to correlate with the background level of dopamine in the basal ganglia. The increased level of dopamine was indeed observed in mice experimentally infected both with Toxoplasma [19] and CMV [49].

The specific neurological mechanism underlying the association between the infections and novelty seeking was not the subject of the present study. The available results of neuroimmunological studies, however, suggest that several cytokines engaged in inflammation processes, like interleukins 1, 2 and 6, directly influence the level and turnover of many neuromodulators, including dopamine [50-53]. An extremely low concentration of interleukin 2 (IL-2) is able to potentiate dopamine release evoked by number of different stimuli, including $\mathrm{K}^{+}$depolarization in mesencephalic cell cultures [54] and striatal slices [55]. Injections of IL-2 into the rat striatum have been shown to induce turning behaviors in rats that are typical of perturbation of the dopaminergic system [56] and subcutaneously administered IL-2 significantly increases locomotor activity of mice in the elevated plus-maze test [55]. Serious 
neuropsychiatric side effects demanding acute intervention regularly occur in oncological patients treated with IL-2 and lymphokine-activated killer cells $[55,57,58]$. Dormant forms of Toxoplasma and CMV persist in the brain of infected individuals for many years. The activation of acute disease in immunocompromised patients and immunohistochemical data obtained on mice [59] suggest that under normal conditions both diseases are kept in latent form by the host immune system. Local immune processes in the brain of subjects with latent infections are probably accompanied by local disturbances in particular cytokine levels [60-64]. This can influence the background level of neuromodulators and secondarily some of the personality dimensions.

It has been reported repeatedly that both toxoplasmosis and contact with cat, the definitive host of Toxoplasma gondii, are associated with higher risk of schizophrenia [2028]. Similarly, schizophrenia was reported to correlate with CMV infection [65]. The background level of dopamine is supposed to play an important role in etiology of schizophrenia [66-68] and autoimmune-like effects on the dopamine system have been proposed as a possible mechanism involved in the pathogenesis of schizophrenia and Parkinson's disease [69]. Clinical investigations have detected increased levels of IL-2 in the CSF of schizophrenic patients manifesting symptoms of psychosis [70,71]. It can be speculated that the local inflammation-induced increase in dopamine in the brain of infected subjects can be in fact the missing link between schizophrenia and Toxoplasma or CMV infection.

\section{Conclusion}

Toxoplasma and cytomegalovirus probably induce a decrease of novelty seeking of infected subjects. As the cytomegalovirus spreads in population by direct contact (not by predation as with Toxoplasma), the observed changes are the byproduct of brain infections rather than the result of manipulation activity of a parasite. Four independent lines of indirect evidence, namely direct measurement of neurotransmitter concentration in mice, the nature of behavioral changes in rodents, the nature of personality changes in humans, and the observed association between schizophrenia and toxoplasmosis, suggest that the changes of dopamine concentration in brain tissue could play a role in behavioral changes of infected hosts.

\section{Competing interests}

The author(s) declare that they have no competing interests.

\section{Authors' contributions}

$\mathrm{MN}$ and JF designated the study, wrote the manuscript and participated in analyses. $\mathrm{JH}, \mathrm{JK}, \mathrm{JH}$ and MP collected the data, participated in analyses and in manuscript writ- ing. KR did serological analyses. All authors read and approved the final manuscript.

\section{Acknowledgements}

This research was supported by The Stanley Medical Research Institute (grant 0I-02 I), GACR -406/04/0097 and by the Czech Ministry of Education (grant 0021620828).

\section{References}

I. Hutchison WM, Aitken PP, Wells BWP: Chronic Toxoplasma infections and motor performance in the mouse. Ann Trop Med Parasitol 1 980, 74:505-510.

2. Witting PA: Learning capacity and memory of normal and Toxoplasma-infected laboratory rats and mice. Z Parasitenkd 1979, 61:29-5I.

3. Hutchison WM, Aitken PP, Wells BWP: Chronic Toxoplasma infection and familiarity-novelty discrimination in the mouse. Ann Trop Med Parasitol 1980, 74: I45-I50.

4. Hay J, Hutchison WM, Aitken PP, Graham DI: The effect of congenital and adult-acquired Toxoplasma infections on activity and responsiveness to novel stimulation in mice. Ann Trop Med Parasitol 1983, 77:483-495.

5. Hay J, Aitken PP, Hair DM, Hutchison WM, Graham DI: The effect of congenital Toxoplasma infection on mouse activity and relative preference for exposed areas over a series of trials. Ann Trop Med Parasitol 1984, 78:6I I-6I8.

6. Hay J, Aitken PP, Arnott MA: The influence of Toxoplasma infection on the spontaneous running activity of mice. $Z$ Parasitenkd 1985, 71:459-462.

7. Hay J, Hutchison WM, Aitken PP: Congenital Toxoplasma infection and response to novelty in mice. Ann Trop Med Parasitol 1983, 77:437-439.

8. Hay J, Aitken PP, Graham DI: Toxoplasma infection and response to novelty in mice. $Z$ Parasitenkd 1984, 70:575-588.

9. Hrda S, Votypka J, Kodym P, Flegr J: Transient nature of Toxoplasma gondii-induced behavioral changes in mice. J Parasitol 2000, 86:657-663.

10. Webster JP: The effect of Toxoplasma gondii and other parasites on activity levels in wild and hybrid Rattus norvegicus. Parasitology 1994, 109:583-589.

11. Webster JP, Brunton CFA, Macdonald DW: Effect of Toxoplasma gondii upon neophobic behaviour in wild brown rats, Rattus norvegicus. Parasitology 1994, 109:37-43.

12. Berdoy M, Webster JP, Macdonald DW: Fatal attraction in rats infected with Toxoplasma gondii. Proc Biol Sci 2000, 267:1591-1594

13. Havlicek J, Gasova Z, Smith AP, Zvara K, Flegr J: Decrease of psychomotor performance in subjects with latent 'asymptomatic' toxoplasmosis. Parasitology 200 I, I 22:5I5-520.

14. Flegr J, Havlicek J, Kodym P, Maly M, Smahel Z: Increased risk of traffic accidents in subjects with latent toxoplasmosis: a retrospective case-controlstudy. BMC Infect Dis 2002, 2:art-I I.

15. Flegr J, Hrdy I: Influence of chronic toxoplasmosis on some human personality factors. Folia Parasitol 1994, 4I: 122-126.

16. Flegr J, Zitkova S, Kodym P, Frynta D: Induction of changes in human behaviour by the parasitic protozoan Toxoplasma gondii. Parasitology 1996, I I3:49-54.

17. Flegr J, Kodym P, Tolarova V: Correlation of duration of latent Toxoplasma gondii infection with personality changes in women. Biol Psychol 2000, 53:57-68.

18. Flegr J, Preiss M, Klose J, Havlicek J, Vitakova M, Kodym P: Decreased level of psychobiological factor novelty seeking and lower intelligence in men latently infected with the protozoan parasite Toxoplasma gondii Dopamine, a missing link between schizophrenia and toxoplasmosis? Biol Psychol 2003, 63:253-268.

19. Stibbs HH: Changes in brain concentrations of catecholamines and indoleamines in Toxoplasma gondii infected mice. Ann Trop Med Parasitol 1985, 79:153-I57.

20. Minto A, Roberts FJ: The psychiatric complications of toxoplasmosis. Lancet 1959:1 180-1 I82.

21. Robertson JS: Toxoplasma skin- and dye-test surveys of severely subnormal patients in Lincolnshire. J Hyg Camb 1965, 63:89-98. 
22. Kramer W: Frontiers of neurological diagnosis in acquired toxoplasmosis. Psych Neurol Neurochir 1966, 69:43-64.

23. Ladee GA, Scholten JM, Meyes FEP: Diagnostic problems in psychiatry with regard to acquired toxoplasmosis. Psych Neurol Neurochir 1966, 69:65-82.

24. Yolken RH, Bachmann S, Ruslanova I: Antibodies to Toxoplasma gondii in individuals with first- episode schizophrenia. Clin Infect Dis 2001, 32:1247-1247.

25. Torrey EF, Yolken RH: Toxoplasma gondii and schizophrenia. Emerg Infect Dis 2003, 9:1375-1380.

26. Torrey EF, Yolken RH: Could schizophrenia be a viral zoonosis transmitted from house cats. Schizophrenia Bull 1995, 21:|67-17|.

27. Torrey EF, Rawlings R, Yolken RH: The antecedents of psychoses: a case-control study of selected risk factors. Schizoph Res 2000, 46: 17-23.

28. Torrey EF, Yolken RH: The schizophrenia-rheumatoid arthritis connection: Infectious, immune, or both? Brain Beh Immun 2002, I5:40I-4I0.

29. Cloninger CR: The genetics and psychobiology of the sevenfactor model of personality. In Biology of personality disorders Edited by: Silk KR. Washington,DC, American Psychiatric Press, Inc.; 1998:63-92.

30. Wiesbeck GA, Mauerer C, Thome J, Jakob F, Boening J: Neuroendocrine support for a relationship between "novelty seeking" and dopaminergic function in alcohol-dependent men. Psychoneuroendocrinology 1995, 20:755-761.

31. Ruegg RG, Gilmore J, Ekstrom RD, Corrigan M, Knight B, Tancer M, Leatherman ME, Carson SW, Golden RN: Clomipramine challenge responses covary with Tridimensional Personality Questionnaire scores in healthy subjects. Biol Psychiatry 1997, 42:1123-1129.

32. Gerra G, Zaimovic A, Timpano M, Zambelli U, Begarani M, Marzocchi GF, Ferri M, Delsignore R, Brambilla F: Neuroendocrine correlates of temperament traits in abstinent opiate addicts. Journal of Substance Abuse 2000, I I:337-354.

33. Hansenne M, Pinto E, Pitchot W, Reggers J, Scantamburlo G, Moor M, Ansseau M: Further evidence on the relationship between dopamine and novelty seeking: a neuroendocrine study. Person Indiv Differ 2002, 33:967-977.

34. Kodym P, Malý M, Svandová E, Lekatková $H$, Badoutová M, Vlková J, Benes C, Zástera M: Toxoplasma in the Czech Republic 19231999: first case to widespread outbreak. Int J Parasitol 2000, 30: $11-18$.

35. Britt W]: Human cytomegalovirus overview: The virus and its pathogenic mechanisms. Baillieres Clin Infect Dis 1996, 3:307-325.

36. Jones J, Lopez A, Wilson M: Congenital toxoplasmosis. Am Fam Phys 2003, 67:2131-2I38.

37. Arribas JR, Storch GA, Clifford DB, Tselis AC: Cytomegalovirus encephalitis. Ann Intern Med 1996, I 25:577-587.

38. Israelski DM, Chmiel JS, Poggensee L, Phair JP, Remington JS: Prevalence of Toxoplasma infection in a cohort of homosexual men at risk of AIDS and toxoplasmic encephalitis. J Acquired Immune Defic Syndr 1993, 6:4I4-4I8.

39. Da Cunha S, Ferreira E, Ramos I, Martins R, De FL, Borges JL, CorteReal R, Mota A, Melico-Silvestre A, Furtado AL: Cerebral toxoplasmosis after renal transplantation. Case report and review. Acta Med Port 1994, 7:S6I-S66.

40. Cinque $P$, Marenzi R, Ceresa D: Cytomegalovirus infections of the nervous system. Intervirology 1997, 40:85-97.

4I. Arendt G, von Giesen H], Hefter H, Neuen-Jacob E, Roick H, Jablonowski $\mathrm{H}$ : Long-term course and outcome in AIDS patients with cerebral toxoplasmosis. Acta Neurol Scand 1999, I00:178-184.

42. Cloninger CR, Przybeck TR, Svrakic DM, Wetzel RD: The temperament and character inventory (TCI): a guide to its development and use. Center for Psychobiology of Personality, St.Louis Missouri, Washington University Press; 1994.

43. Kožený J, Tisanská L: Formální vlastnosti dotazníku TCI testované na datech adolescentù. CS Psychol 1998, 42:75-83.

44. Preiss M, Klose J: Diagnostika poruch osobnosti pomocí teorie C R Cloningera. Psychiatrie 2003, 4:226-23I.

45. Otis AS: Edited by: Otis Quick-Scoring Mental Ability Test, New Edition. Tarrytown-on-Hudson, NY, Word Book Co; 1954.

46. Pokorny J, Fruhbauer Z, Polednakova S, Sykora J, Zastera M, Fialova D: Stanoveni antitoxoplasmickych protilatek IgG netodou
ELISA (Assessment of antitoxoplasmatic IgG antibodies with the ELISA method). Cs Epidem 1989, 38:355-36I.

47. Warren J, Sabin AB: The complement fixation reaction in toxoplasmic infection. Proc Soc Exp Biol Med 1942, 5 I: I I-16.

48. Rothschild DM, O'Grady M, Wecker L: Neonatal cytomegalovirus exposure decreases prepulse inhibition in adult rats: implications for schizophrenia. J Neurosci Res 1999, 57:429-434.

49. O'Kusky JR, Boyes BE, Walker DG, McGeer EG: Cytomegalovirus infection of the developing brain alters catecholamine and indoleamine metabolism. Brain Res 1991, 559:322-330.

50. Dunn AJ: Systemic interleukin-I administration stimulates hypothalamic norepinephrine metabolism parallelling the increased plasma corticosterone. Life Sci 1988, 43:429-435.

5I. Kabiersch A, del Rey A, Honegger CG, Besedovsky HO: Interleukin-I induces changes in norepinephrine metabolism in the rat brain. Brain Behav Immun 1988, 2:267-274.

52. Araujo DM, Lapchak PA, Collier B, Quirion R: Localization of interleukin-2 immunoreactivity and interleukin-2 receptors in the rat brain: interaction with the cholinergic system. Brain Res 1989, 498:257-266.

53. Zalcman S, Murray L, Dyck DG, Greenberg AH, Nance DM: Interleukin-2 and -6 induce behavioral-activating effects in mice. Brain Res 1998, 81 I: III-I2I.

54. Alonso R, Chaudieu I, Diorio J, Krishnamurthy A, Quirion R, Boksa P: Interleukin-2 modulates evoked release of $[3 \mathrm{H}]$ dopamine in rat cultured mesencephalic cells. I Neurochem 1993, 6I:1284-I290.

55. Petitto JM, McCarthy DB, Rinker CM, Huang Z, Getty T: Modulation of behavioral and neurochemical measures of forebrain dopamine function in mice by species-specific interleukin- 2 . J Neuroimmunol 1997, 73:183-190.

56. De Sarro GB, Masuda Y, Ascioti C, Audino MG, Nistico G: Behavioural and ECoG spectrum changes induced by intracerebral infusion of interferons and interleukin 2 in rats are antagonized by naloxone. Neuropharmacology 1990, 29:167-179.

57. Denicoff KD, Rubinow DR, Papa MZ, Simpson C, Seipp CA, Lotze MT, Chang AE, Rosenstein D, Rosenberg SA: The neuropsychiatric effects of treatment with interleukin-2 and lymphokineactivated killer cells. Ann Intern Med 1987, 107:293-300.

58. West WH, Tauer KW, Yannelli JR, Marshall GD, Orr DW, Thurman GB, Oldham RK: Constant-infusion recombinant interleukin-2 in adoptive immunotherapy of advanced cancer. New Engl Med 1987, 3 I 6:898-905.

59. Conley FK, Jenkins KA: Immunohistological study of the anatomic relationship of Toxoplasma antigens to the inflammatory response in the brains of mice chronically infected with Toxoplasma gondii. Infect Immun | 981, 31: I | 84-। | 92.

60. Arsenijevic D, Girardier L, Seydoux J, Chang HR, Dulloo AG: Altered energy balance and cytokine gene expression in a murine model of chronic infection with Toxoplasma gondii. Am J Physiol 1997, 272:908-917.

61. Schluter D, Kaefer N, Hof H, Wiestler OD, Deckertschluter M: Expression pattern and cellular origin of cytokines in the normal and Toxoplasma gondii-infected murine brain. Am J Pathol 1997, I 50:1021-1035.

62. Denkers EY, Gazzinelli RT: Regulation and function of T-cellmediated immunity during Toxoplasma gondii infection. Clin Microbiol Rev 1998, I I :569-588.

63. Cai GF, Radzanowski T, Villegas EN, Kastelein R, Hunter CA: Identification of STAT4-dependent and independent mechanisms of resistance to Toxoplasma gondii. J Immunol 2000, 165:2619-2627.

64. Fischer HG, Reichmann G: Brain dendritic cells and macrophages/microglia in central nervous system inflammation. Immunol 200I, 166:2717-2726.

65. Albrecht P, Torrey EF, Boone E, Hicks JT, Daniel N: Raised cytomegalovirus-antibody level in cerebrospinal fluid of schizophrenic patients. Lancet 1980, 2:769-772.

66. Yolken RH, Torrey EF: Hypothesis of a viral etiology in bipolar disorder. In Bipolar disorders. Basic mechanisms and therapeutic implications Edited by: Soares JC and Gershon S. New York, Marcel Dekker, Inc; 2002:305-3 I5.

67. Carlsson A: The current status of the dopamine hypothesis of schizophrenia. Neuropsychopharmacology 1988, 1:179-186.

68. Sawa A, Snyder SH: Schizophrenia: diverse approaches to a complex disease. Science 2002, 296:692-695. 
69. Abramsky O, Litvin Y: Automimmune response to dopaminereceptor as a possible mechanism in the pathogenesis of Parkinson's disease and schizophrenia. Perspect Biol Med 1978, 22: $104-1 \mid 4$.

70. Licinio J, Seibyl JP, Altemus M, Charney DS, Krystal JH: Elevated CSF levels of interleukin-2 in neuroleptic-free schizophrenic patients. Am J Psychiatry 1993, I50:1408-14I0.

71. McAllister CG, van Kammen DP, Rehn TJ, Miller AL, Gurklis J, Kelley ME, Yao J, Peters JL: Increases in CSF levels of interleukin-2 in schizophrenia: effects of recurrence of psychosis and medication status. Am J Psychiatry 1995, I52:1291-1297.

\section{Pre-publication history}

The pre-publication history for this paper can be accessed here:

http://www.biomedcentral.com/1471-2334/5/54/prepub

Publish with Biomed Central and every scientist can read your work free of charge

"BioMed Central will be the most significant development for disseminating the results of biomedical research in our lifetime. "

Sir Paul Nurse, Cancer Research UK

Your research papers will be:

- available free of charge to the entire biomedical community

- peer reviewed and published immediately upon acceptance

- cited in PubMed and archived on PubMed Central

- yours - you keep the copyright

Submit your manuscript here:

http://www.biomedcentral.com/info/publishing_adv.asp
BioMedcentral 